\title{
A gluténérzékenység extraintestinalis spektruma
}

\author{
Fedor István dr. ${ }^{1}$ - Zöld Éva dr. ${ }^{1}$ - Barta Zsolt dr. ${ }^{2,3}$ \\ ${ }^{1}$ Debreceni Egyetem, Általános Orvostudományi Kar, Belgyógyászati Intézet, Klinikai Immunológiai Tanszék, \\ Debrecen \\ ${ }^{2}$ Debreceni Egyetem, Általános Orvostudományi Kar, Gasztroenterológiai Nem Önálló Tanszék, \\ Belgyógyászati Intézet, Debrecen \\ ${ }^{3}$ Debreceni Egyetem, Általános Orvostudományi Kar, Kihelyezett Infektológiai Tanszék, Debrecen
}

\begin{abstract}
A coeliakia (gluténszenzitív enteropathia) széleskörűen ismert betegség, mégis számos tévhit övezi. Bármely életkorban jelentkező, több szervrendszert érintő, változatos formákban mutatkozó autoimmun betegség, amelyet sokan tévesen csak a gastrointestinalis (GI-) rendszerre korlátozódó kórfolyamatként ismernek. Gondot jelent, hogy idősebb életkorban sokszor késik a diagnózis, mert szintén tévesen a gyermekkorral asszociálják. Árnyalja a képet, hogy a „klasszikusan” ismert gastrointestinalis tünetek kevésbé prevalensek felnőttkorban, és gyakrabban más szervrendszerek érintettsége okozta tünetek (idegrendszeri, cardiovascularis, hepatobiliaris, hematológiai vagy endokrin rendellenességek) miatt kerül a beteg orvoshoz. A coeliakia extraintestinalis manifesztációi kevésbé ismertek, viszont gyakoriak, ami indokolja azok ismertetését. Közleményünk célja egy rövid, nem teljes körü áttekintés a gluténérzékenység extraintestinalis megjelenési formáiról, gyakrabban leírt társbetegségekről a régebbi és újabb szakirodalom alapján.
\end{abstract}

Orv Hetil. 2019; 160(34): 1327-1334.

Kulcsszavak: coeliakia, glutén, autoimmun betegség, gastrointestinalis betegség

\section{The extraintestinal spectrum of gluten sensitivity}

Although celiac disease (gluten-sensitive enteropathy) is a relatively well known malady, yet is surrounded by several misconceptions. It is in fact, a multi-systemic autoimmune disorder with a wide spectrum of possible presentations, though most clinicians regard it as a solely gastrointestinal disease. Another misconception that it is a disease of paediatric age group. Thus, the diagnosis of adult or elderly patients is often delayed. Recognition of the disease in the adults can be challenging, as there are less pronounced gastrointestinal symptoms, and patients present with other manifestations (i.e., neurologic, cardiovascular, hepatobiliary, or hematologic involvement are common). As these extraintestinal manifestations are less well known among practicing physicians, here we propose a brief overview of these. We aimed to summarize the available literature on the extraintestinal manifestations associated with gluten sensitivity.

Keywords: celiac disease, gluten, autoimmunity, gastrointestinal disease

Fedor I, Zöld É, Barta Zs. [The extraintestinal spectrum of gluten sensitivity]. Orv Hetil. 2019; 160(34): 1327-1334.

(Beérkezett: 2019. március 28.; elfogadva: 2019. április 19.)

\section{Rövidítések}

$\mathrm{AHA}=$ autoimmun haemolyticus anaemia; $\mathrm{AI}=$ autoimmun; AIDP $=$ (acute inflammatory demyelinating polyneuropathy) akut gyulladásos demyelinisatiós polyneuropathia; $\mathrm{AIH}=$ autoimmun hepatitis; anti-DGP = deamidált gliadinpeptid elleni antitest; anti-TPO = tireoperoxidáz elleni antitest; $\mathrm{CHF}=$ (congestive heart failure) pangásos szívelégtelenség; CIMT = (carotid intima-media thickness) carotis intima-media vastag- ság; $\mathrm{CV}=$ cardiovascularis; $\mathrm{DCM}$ = dilatativ cardiomyopathia; EATL $=($ enteropathy-associated T-cell lymphoma) enteropathiához társuló (asszociált) T-sejtes lymphoma; EEG = elektroencefalográfia; $\mathrm{EF}$ = ejekciós frakció; $\mathrm{EIM}=$ extraintestinalis manifesztáció; EMA = endomysiumellenes antitest; eTG = epidermalis transzglutamináz; FMD = (flow-mediated vasodilation) áramlás közvetítette vasodilatatio; $\mathrm{GA}=$ gluténataxia; GAD = glutamát-dekarboxiláz; GI = gastrointestinalis; GMÉ = 
gluténmentes étrend; GSE = gluténszenzitív enteropathia; Hcy = homocisztein; HLA = humán leukocytaantigén; HPG = (hypothalamo-pituitary-gonadal) hypothalamohypophysialisgonadalis; IFN $\gamma=$ interferon- $\gamma$; IgA = immunglobulin-A; IGF $=$ (insulin-like growth factor) inzulinszerü növekedési faktor; IgG = immunglobulin-G; IL = interleukin; ILY = intraepithelialis lymphocytosis; ITP = immunthrombocytopeniás purpura; $\mathrm{LBW}=$ (low birth weight $)$ alacsony születési súly; LPS $=$ lipopoliszacharid; $\mathrm{LVD}=$ (left ventricular diameter) bal kamrai átmérő; $\mathrm{MMA}=($ methylmalonic acid $)$ metil-malonát; $\mathrm{MMP}=$ mátrix-metalloproteáz; NAFLD $=$ (non-alcoholic fatty liver disease) nem alkoholos zsírmájbetegség; NCGS = nem coeliakiás gluténszenzitivitás; $\mathrm{NMO}=$ neuromyelitis optica; $\mathrm{PWV}=$ (pulse wave velocity) pulzushullám-sebesség; RCD = refrakter coeliakia; RLS = (restless leg syndrome) nyugtalanláb-szindróma; SCFA = (short-chain fatty acid $)$ rövid szénláncú zsírsav; SGOT = szérum-glutamát-oxálacetát-transzamináz; SGPT = szérum-glutamát-piruvát-transzamináz; T1DM = (type 1 diabetes mellitus) l-es típusú diabetes; TG = transzglutamináz; $\mathrm{TNF} \alpha=$ tumornekrózisfaktor $-\alpha ; \mathrm{TPO}=$ tireoperoxidáz; $\mathrm{tTG}=$ (tissue transglutaminase) szöveti transzglutamináz
A coeliakia több szervrendszert érintő immunbetegség; kiváltó tényezője a búza és rokonfajok, például rozs, árpa, hibridek fó tárolófehérjéi (1. táblázat). Kórfolyamata hátterében feltehetőleg molekuláris mimikri állhat.

Kialakulásában a genetikai tényezők közül bizonyos HLA-allélek megléte nélkülözhetetlen. Gyakorlatilag valamennyi, GSE-ben szenvedő beteg HLA-DQ2- (90\%) vagy DQ8- (5\%) variánssal bír. Továbbá közel 40 nemHLA-gén asszociációját is megfigyelték [1]. Mint más gastrointestinalis betegségekben, coeliakiában is felmerült a bélmikrobiom szerepe. Néhány tanulmány igazolta is a commensalis flóra eltéréseit, de egyelöre feltáratlan, hogy ez oka-e vagy következménye a betegségnek [2]. Ritka betegségnek tartották, ma nagyjából a népesség 1-1,5\%-ában diagnosztizált, de valójában még gyakoribb lehet, fel nem derített, tünetmentes esetek következtében (coeliakiás jéghegy).

Típusos a duodenum-nyálkahártya érintettsége: a nyálkahártya-elváltozások osztályozására a Marsh-Ober-

1. táblázat | Különböző szervrendszerek érintettsége

\begin{tabular}{|c|c|c|}
\hline Érintett szervrendszer & Megjelenési forma, kórállapotok & Megjegyzés \\
\hline $\begin{array}{l}\text { Központi idegrendszer, } \\
\text { cerebellum }\end{array}$ & $\begin{array}{l}\text { - Cerebellaris ataxia. } \\
\text { - Migrén, gluténencephalopathia. } \\
\text { - Epilepsziás görcsök, cerebralis meszesedés. } \\
\text { - Neuropszichiátriai zavarok, kognitív dysfunctio. }\end{array}$ & $\begin{array}{l}\text { A KIR-t érintó társbetegség előfordulhat: } \\
\text { - sclerosis multiplex, } \\
\text { - neuromyelitis optica, } \\
\text { - amyotrophiás lateralsclerosis. }\end{array}$ \\
\hline Perifériás idegrendszer & $\begin{array}{l}\text { - Perifériás neuropathia. } \\
\text { - Dysautonomia. }\end{array}$ & $\begin{array}{l}\text { - NCGS esetén is gyakoriak. } \\
\text { - Autonóm dysfunctio sokszor visszamarad. }\end{array}$ \\
\hline Cardiovascularis rendszer & $\begin{array}{l}\text { - Autoimmun dilatativ cardiomyopathia. } \\
\text { - Fokozott atherosclerosis. } \\
\text { - Endothelialis dysfunctio, thrombogenitas. }\end{array}$ & $\begin{array}{l}\text { - Prediszpozíció myocardialis infarctusra, cerebrovas- } \\
\text { cularis történésekre, más thromboticus szövődmé- } \\
\text { nyekre. }\end{array}$ \\
\hline Endokrin rendszer & $\begin{array}{l}\text { - Hypophysitis, autoimmun agyalapimirigy-gyulladás. } \\
\text { - Thyreoiditisek (Hashimoto, Graves). } \\
\text { - l-es típusú diabetes mellitus. }\end{array}$ & $\begin{array}{l}\text { - A leggyakrabban diagnosztizált társ autoimmun } \\
\text { kórképek a TIDM és a Hashimoto-thyreoiditis! } \\
\text { - Genetikai fogékonyság, átfedés a hajlamosító } \\
\text { HLA-génekben. }\end{array}$ \\
\hline Hepatobiliaris rendszer & $\begin{array}{l}\text { - Autoimmun hepatitis. } \\
\text { - Enyhe hypertransaminasaemia. } \\
\text { - Primer szklerotizáló cholangitis. } \\
\text { - Primer biliaris cirrhosis. }\end{array}$ & $\begin{array}{l}\text { - Az étrendre sokszor kiválóan reagálnak a májat érintő } \\
\text { formák. } \\
\text { - Társuló autoimmun betegségek (PBC, PSC) kapcsán } \\
\text { közös genetikai tényezők. }\end{array}$ \\
\hline Reproduktív rendszer & $\begin{array}{l}\text { - Késői menarche, korai menopauza. } \\
\text { - Csökkent fertilitás. } \\
\text { - A terhességi szövődmények nagy száma. } \\
\text { - Spontán vetélés. } \\
\text { - A magzat növekedésbeli elmaradása, } \\
\text { alacsony születési súly, koraszülés. } \\
\text { - Szekunder amenorrhoea. }\end{array}$ & $\begin{array}{l}\text { - A meddőség kivizsgálásának része a GSE kizárása. } \\
\text { - A manifesztációk egy részét vasculitis magyarázza, így } \\
\text { vascularis rendellenességként is felfogható. } \\
\text { - Férfiaknál kisebb számban vizsgálták, kevésbé ismert. }\end{array}$ \\
\hline Kültakaró & $\begin{array}{l}\text { - Dermatitis herpetiformis. } \\
\text { - Ekcéma. } \\
\text { - Psoriasis. }\end{array}$ & $\begin{array}{l}\text { - A DH (Duhring) szintén AI-betegség, epidermalis } \\
\text { transzglutamináz elleni autoantitestek jelenlétével. } \\
\text { - Psoriasis, mint társ-AI-betegség, gyakrabban fordul } \\
\text { elő GSE esetén. }\end{array}$ \\
\hline Haematopoeticus rendszer & $\begin{array}{l}\text { - Vashiányos anaemia. } \\
\text { - Thrombocytosis. } \\
\text { - Lymphomák. } \\
\text { - Autoimmun hátterű cytopeniák. }\end{array}$ & $\begin{array}{l}\text { - Per os vaspótlásra refrakter anaemia. } \\
\text { - Vashiány mellett folsav- és } \mathrm{B}_{12} \text {-hiány is előfordulhat. } \\
\text { - Nemcsak az EATL, más lymphomák is gyakoribbak! } \\
\text { - A thrombocytosis általában nem súlyos fokú, de } \\
\text { kivételek lehetnek. } \\
\text { - AI-mechanizmusú anaemia, thrombocytopenia is } \\
\text { előfordulhat. }\end{array}$ \\
\hline
\end{tabular}

$\mathrm{AI}=$ autoimmun; $\mathrm{DH}=$ dermatitis herpetiformis; EATL $=$ enteropathiához társuló (asszociált) T-sejtes lymphoma; GSE = gluténszenzitív enteropathia; $\mathrm{KIR}=$ központi idegrendszer; NCGS = nem coeliakiás gluténszenzitivitás; PBC = primer biliaris cirrhosis; PSC = primer szklerotizáló cholangitis; T1DM = 1-es típusú diabetes 
huber-rendszert használják. Szerológiai diagnosztikája érzékeny, és fajlagos autoantitestek kimutatásán alapszik, így az endomysiumellenes antitestek (EMA), illetve a transzglutamináz-2 (szöveti - tissue transglutaminase tTG) ellen termelt antitestek meghatározásán [1]. A betegek körében gyakoribb a szelektív IgA-hiány, mint a nem coeliakiás populációban. Így érdemes össz-IgAszinteket is meghatározni és IgG-típusú ellenanyagokat is vizsgálni. Egyre nagyobb szerepet kap a deamidált gliadinpeptid elleni antitest is (anti-DGP) [3], amely igen fajlagos (bár kevésbé érzékeny) teszt.

Sokan megkérdőjelezik az entitás meglétét, de az ún. „nem coeliakiás gluténérzékenység” (NCGS) gyakorisága meghaladhatja a GSE-ét, egyes populációkban a 10\%ot is elérheti a betegek aránya [4]. Patogenezise homályos, de egyes vizsgálatok igazoltak immundysfunctiót [5]. Specifikus markere nem ismert, nincs szoros asszociáció a coeliakiára jellemző HLA-típusokkal, s nem fordulnak elő jellegzetes autoantitestek. A bélnyálkahártyamintákon kóros szövettani eltérés nem látható, legfeljebb kismértékü intraepithelialis lymphocytosis (ILY), amely nem specifikus. Az ILY fokozott kockázatot jelent AIbetegségekre, és a betegek egy részénél alaposabb vizsgálat után „valódi” coeliakiát lehet diagnosztizálni [4].

A coeliakia változatos megjelenését magyarázhatja, hogy a TG-enzimek széles körben megtalálhatók a szervekben, szövetekben. Szinte bárhol számítani lehet autoimmunitás közvetítette károsodásra [6]. Számos szervrendszert érinthetnek a kórfolyamatok, ezek rövid összefoglalása a 1. táblázatban található.

$\mathrm{Az}$ egyetlen hatásos terápia a gluténmentes étrend (GMÉ). Kísérletes próbálkozások voltak a rendellenes bélnyálkahártya-barriermúködés helyreállítására (larazotid-acetát, AT-1001), gluténfehérjék emésztésének segítésére, akár immunszuppresszív kezelésekre is, de ezek csupán kis mennyiségú expozíció esetén hatásosak [1].

\section{Extraintestinalis manifesztációk, szervrendszerek érintettsége}

Ismeretük segíthet a betegség korai felismerésében, javítva a betegek életminőségét, csökkenti az esetleges szövődmények kialakulását. Háttérmagyarázatként felmerült a malabszorpció következtében létrejövő mikrotápanyag-hiány. Ez ritkán helytálló: többségében félresiklott immunmúködés játszik központi szerepet a GI-rendszeren túlterjedő kórfolyamatokban $[6,7]$. Ez igazolható laboratóriumi (autoantitest-szerológia, gyulladásos markerek) és mikroszkópos (immunfluoreszcencia, szövettani mintákon immunsejtes infiltráció) vizsgálatokkal egyaránt.

\section{Idegrendszeri szövődmények}

Változatos formákban jelentkezhetnek, érdemes ezekre is gondolni ismeretlen eredetű ideggyógyászati panaszok
2. táblázat | Coeliakia (gluténszenzitív enteropathia)- összefoglalás

Fő pontok, útravaló

- Multiszisztémás autoimmunitás, kiterjedt szervrendszeri tünetek

- Bármilyen életkorban kifejlődhet

- Magas kockázat társuló autoimmun betegségekre

- Fokozott hajlam neurológiai elváltozásokra

- Fokozott szív-ér rendszeri kockázat és terhességi szövődmények

- Jelenleg az egyetlen effektív kezelés a gluténmentes étrend

esetén. A betegségek szélesebb elismertsége és patofiziológiai háttérkutatása az elmúlt két évtizedben kapott jelentősebb szerepet. Idegrendszeri érintettség előfordulhat „NCGS-” pácienseknél is, így a coeliakiával párhuzamosan tárgyaljuk [8].

A legismertebb a cerebellaris ataxia (gluténataxia, GA), amely típusosan alsó végtagi koordinációs és járászavarokban mutatkozik meg. Gyakori GSE- és NCGSbetegeknél is, bár az utóbbiak esetén gyakoribb idegrendszeri elváltozás a perifériás neuropathia [8]. Társulhat szemmozgászavarokkal (a betegek akár négyötödénél), nystagmusszal, felső végtagi mozgászavarokkal. Ritkán kapcsolódhat hozzá nyelészavar, dysarthria, myoclonusok (EEG-jelzések szerint kérgi eredetű), lágy szájpadi tremor. Az ataxia súlyossága széles spektrumon mutatkozhat, előrehaladott formákban a beteg járásképtelen, kerekes székhez kötött, de a járóképes betegek is segítségre szorulhatnak. A betegek általában - több mint kétharmaduk - enyhe ataxiával érintettek. Összevetve a GSE- és NCGS-eseteket, az előbbieknél nagyobb arányban reprezentáltak középsúlyos és súlyos tünetek, a különbségek nem jelentősek [8].

A mozgatókör gluténnel összefüggésbe hozható rendellenességei ritkák [8]. Közülük egyes állapotok autoimmun hátterúek (például 'stiff person' [merev ember] szindróma, glutamát-dekarboxiláz [GAD] elleni antitestekkel, neuromyelitis optica [NMO] - akvaporin-4 ellen irányuló autoantitestek). Más esetekben szerepe lehet a mikronutriens-hiánynak (például vashiánnyal összefüggő restless leg syndrome - RLS). Ritkának számítanak a gyermekkori esetek Guillain-Barré-szindrómával (AIDP - akut inflammatoricus demyelinisatiós polyneuropathia) vagy myelitis transversa kialakulásával $[9,10]$.

Ismert a cerebellaris ataxiák immunmediált kórfolyamata. A kisagyi kórfolyamatokkal asszociált autoantitestek meghatározása - transzglutamináz-6 ellen - a klinikai gyakorlatban egyelőre nem terjedt el. A TG6-ellenes autoantitestek kialakulása nem kötött szigorúan HLA-DQ2 vagy DQ8 jelenlétéhez [8]. A központi idegrendszeri kórfolyamatokban felvetődött gliadinellenes antitestek jelentősége is - molekuláris mimikri révén. Jellemző a vasculitis, gyulladásos beszürődés, csökkent vér-agy gát múködés és hypoperfusio. Az autoantitest-termelés gluténmentes diéta mellett általában megszúnik. Sikertelensége irreverzibilis cerebellaris dysfunctióhoz, kisagyi atrophiához vezethet [11]. A gliadinellenes antitestek 
szerepe neurokognitív zavarok kialakulásában is felvetődött [12-14]. Ugyanezen antigliadin-antitestek keresztreagálhatnak szinapszin-I fehérjékkel, így a neurotranszmitterek fiziológiás múködésével is interferálhatnak [14].

Coeliakiásoknál gyakoribb a perifériás neuropathiák előfordulása, közel 2,5×-es kockázatnövekedéssel az egészséges népességhez képest. A klinikai megjelenés a legtöbbször szimmetrikus, axonhosszfüggő polyneuropathia, sensoros ganglionopathia, ritkán mononeuritis multiplex, myelopathia. Coeliakiában a neuropathia általában súlyosabb az NCGS-ben észlelthez képest [8]. A bántalom az érző- és mozgatókörön túl az autonóm idegrendszert is érintheti. Az autonóm idegrendszeri múködészavarok GMÉ mellett is fennmaradhatnak [15]. A neuropathiás szövődmények nem korlátozódnak a felnőtt populációkra (bár az 50. életév körül jelentkezik a kórfolyamatok többsége).

Magyarázatként felvetették a malabszorpció okozta mikrotápanyag-hiányt. A betegeknek azonban nem mindig vannak hasi panaszaik, patológiás szövettani kép nem mindig látható a bélnyálkahártya szerkezetében, laborvizsgálatok sem igazolnak mikronutriens-hiányt. In vitro vizsgálatokban kisagyi Purkinje-sejt-pusztulást lehetett kiváltani coeliakiás szérummal. Fluoreszcens mikroszkópiával láthatóvá tehetők az autoantitest-lerakódások. Gyulladásos beszürődés, központi idegrendszeri vasculitis jellemző az idegrendszeri kórfolyamatokra coeliakiásoknál [11].

A GSE-betegek körében gyakoribbak a fejfájások az egészséges népességhez viszonyítva, ezeket kísérhetik fehérállomány-beli laesiók [13, 16]. Migrénszerü vagy vizuális tünetekkel járó fejfájások formájában is jelentkezhet, a kialakult fehérállományi elváltozások MR-vizsgálattal vizualizálhatók [17]. A gluténmentes étrend a klinikai tünetek csökkenéséhez, a képalkotókon látható elváltozások rendeződéséhez is hozzájárul. Fejfájások előfordulnak gyermekeknél is, jellemzően kétszeres gyakorisággal a kontrollnépességhez képest [18].

Fokozott hajlam látható coeliakiásoknál epileptikus görcsrohamokra. A klasszikusan GSE-vel asszociált rohamok occipitalis eredetűek, társulhatnak cerebralis meszes gócokkal [16, 19-22]. A coeliakiás betegek cerebralis meszesedéseinek magyarázataként felmerült a folsavhiány. De a betegek folsavszintje általában normális, és a kiegészítés sem hat kedvezően az elváltozásokra. Leírtak temporalis eredetû görcsrohamokat is GSE-vel összefüggésben $[23,24]$. A tünetek sokszor nem reagálnak antiepileptikumokra [21]. NCGS-betegeknél szintén megfigyeltek gyógyszerrezisztens rohamokat, melyek gluténmentes diéta alatt rendeződtek.

Kevésbé kutatott a GSE összefüggése neurokognitív zavarokkal [12-14]. A központi idegrendszeri vasculitis, hypoperfusio, tartós gyulladásos állapot, endothelialis dysfunctio ismeretében logikus következmény lehet a kognitív múködések károsodása [12-14, 16]. A betegeknél a fokozott thromboticus hajlamhoz köthető szövőd-

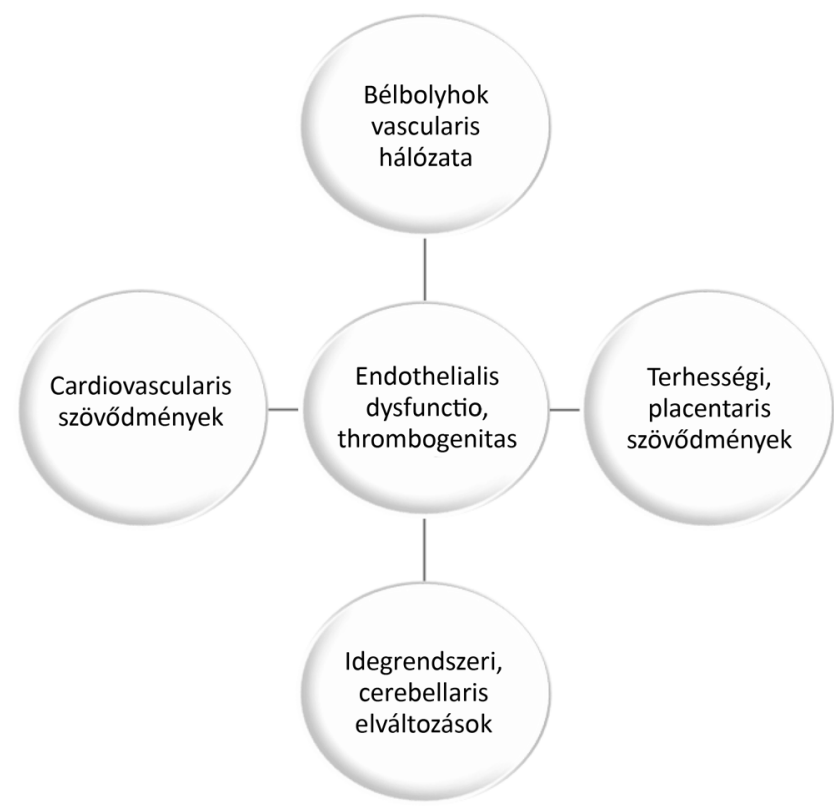

1. ábra

A fokozott thrombogen hajlam és klinikai megjelenése. Számos kórfolyamatban vesz részt az endothelialis dysfunctio és a kóros véralvadékonyság

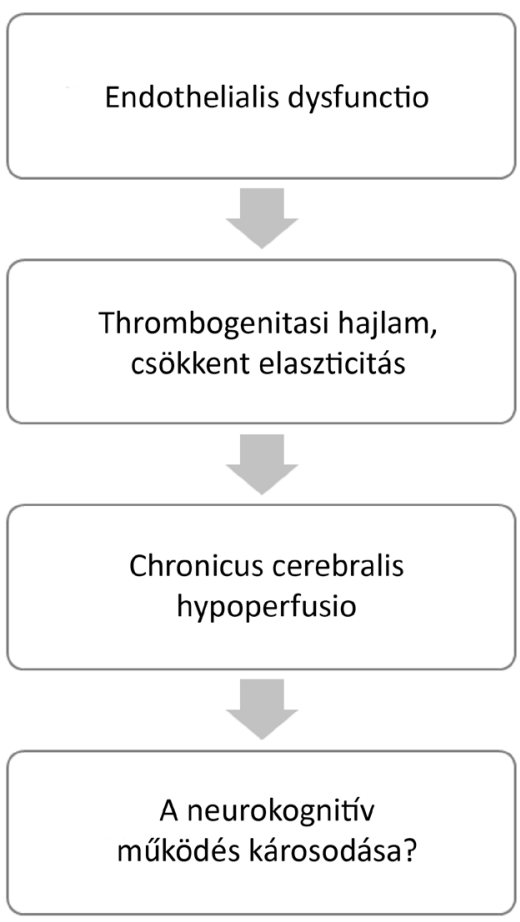

2. ábra $\quad$ A neurokognitív deficit kialakulásának lehetséges folyamata

ményeket az 1 a ábrán tüntettük föl, míg a neurokognitív zavarokhoz vezető feltételezett kórfolyamatot a 2. ábra tartalmazza. Napjainkban egyre ismertebb a cerebellum nagyagykéreggel való kapcsolatrendszere, szerepe a tanulási folyamatokban. Idősebb betegek kognitív múködései sokszor korrelálnak a kisagyi funkciókkal [14]. 


\section{Szív-keringési rendszeri érintettség}

A gluténérzékenység cardiovascularis szövődményekkel is társulhat. Klinikailag - akár már gyermekkorban - dilatativ cardiomyopathia (DCM), illetve pangásos szívelégtelenség $(\mathrm{CHF})$ jelenhet meg $[25,26]$. Terápiájukban a gluténmentes étrend bevezetése kulcsfontosságú [27]. Korai étrendi módosítással a folyamat visszafordítható, a megnövekedett bal kamrai átmérő (LVD) és csökkent ejekciós frakció (EF) normalizálódhat [25,26]. Diétázás hiányában akár transzplantációt igénylő progresszió is lehetséges, ritkán átmeneti immunszuppresszív kezelésre lehet szükség a tüneti kezelésen felül [25]. A szülők szerepe a gyermekkori esetekben kiemelkedő, mivel sajnos akár fatális kimenetellel is számolni lehet [27]. A DCMen túlmenően „idiopathiás”, valvularis és ischaemiás típusok is gyakorabban fordulnak elő coeliakiában. A gluténszenzitivitásban jelen lévő immundysfunctio myocarditisre, pericarditisre való fokozott hajlam révén is a szívmúködés károsodására hajlamosít [25]. Súlyosbító tényező a tiamin ( $\mathrm{B}_{1}$-vitamin)-hiány, melynél a szívizom energiaellátottsága károsodhat.

A keringési rendszert érintő szövődmények egy részét magyarázza a fokozott thromboticus hajlam - a coeliakia thrombophiliás állapotként is értelmezhető - és endothelialis dysfunctio $[25,28]$. A sokszor elfeledett CV-rizikófaktor, a hyperhomocysteinaemia (Hcy) gyakran kísérője a betegségnek, jelentős tényező az érrendszeri szövődmények létrejöttében [25]. K-vitamin-hiányos állapotban az antikoaguláns protein-C és -S szintjének csökkenése hajlamosít thrombosisra. A thromboticus események fơleg a vénás keringést érintik, beleértve a portalis, lienalis, mesenterialis visszereket, cerebralis vénás sinusokat, ugyanakkor artériás thromboemboliás szövődményt - akár cerebralis történés (stroke) vagy myocardialis infarctus formájában - szintén észlelhetünk $[25,26,28]$.

Az elasztikus artériák szerkezeti elváltozásai jellegzetesek. A csökkent elaszticitás megfigyelhető Dopplerultrahanggal végzett pulzusgörbék vizsgálata során, $\mathrm{s}$ a progresszió is követhető. Az artériák élettani múködésének rendellenessége jelezhet szubklinikai atherosclerosist, hajlamot későbbi CV-történésekre. Szigorú GMÉ mellett sem mindig rendeződik a folyamat, az elaszticitás és falmerevség nem tér vissza egészséges értékekre [25].

A carotisrendszeren rendellenes intima-media vastagság (CIMT) mérhetố noninvazívan, B-módú ultrahangvizsgálattal. Ez már a klinikai tünetek megjelenése előtt észrevehető. Romlik a verőeres keringésben mérhetó áramlás közvetítette vasodilatatio (FMD, flowmediated vasodilation), rendellenes lehet a pulzushullám-sebesség (PWV, pulse wave velocity) [25]. Coronariasclerosisra való fokozott hajlam szintén leírásra került $[25,28]$.

\section{Vérképző rendszer}

A per os vaspótlásra nem reagáló vashiányos vérszegénység hátterében gyakran gluténérzékenység áll. A folyamatért felelős a vasfelszívódásban fontos duodenumnyálkahártya károsodása, amelyet a krónikus gyulladás, illetve a vaskészletek sequestratiója ront [29]. Jellemző a gyulladásos markerek emelkedése (például ILl és -6, $\mathrm{TNF} \alpha, \mathrm{IFN} \gamma$ ), illetve a vasraktárak sequestratiója [29].

$\mathrm{A}_{12}$ (kobalamin) és a folsav deficientiája típusosan macrocytás megaloblastos vérszegénységet okoz. Folsavhiánynál ritkábban látni $\mathrm{B}_{12}$-hiányt (mivel a fó felszívódási helye, a terminalis ileum ritkán érintett), kiegészítése mérlegelendő. Diagnosztikájában a szérum folsav- és $\mathrm{B}_{12}$-szintjének mérése mellett a homocisztein (Hcy) vagy metil-malonát (MMA) meghatározása is lehetséges. Mindkét érték magas $B_{12}$-vitamin-hiányban, folsavhiány mellett csak a Hcy emelkedett [29].

Autoimmun mechanizmusú haemolyticus anaemia, illetőleg aplasticus anaemia (csontvelői alulmúködés) is előfordulhat. A $\mathrm{B}_{12}$-malabszorpció szintén lehet AI-hátterú, anaemia perniciosa, parietalis sejtek és intrinszik faktor ellen termelt antitestek következtében [30-32].

Gyakran megfigyelt kismértékű thrombocytosis coeliakiásoknál, a betegek körülbelül kétharmadánál látható. A thrombocytosis mértéke ritkán haladja meg a 600 $\mathrm{M} / \mathrm{L}$ értéket, az extrém magas thrombocytaszám ritkaságnak számít [33].

A thrombocytopenia előfordulása GSE-ben ritka. Az immunthrombocytopeniás purpura (ITP) fóleg gyermekkorban jelentkezhet, ritkán autoimmun haemolyticus anaemiával (AHA) társulhat [29].

A fehérvérsejtek érintettségét illetően klasszikusan a T-sejtes lymphomák egy változata, az enteropathiához társuló (asszociált) T-sejtes lymphoma (EATL) előfordulása ismertebb [34]. A kórkép idősebb korosztályra és refrakter coeliakiára (RCD) jellemző.

Egyéb típusú lymphomák (non-Hodgkin) gyakoribbak GSE-ben, mint az EATL. Coeliakiásoknál a vérképző rendszeri malignitások kockázata fokozott, ennek magyarázata egyelőre nem ismert. A szolid tumorok közül gyakoribbnak találták a vékonybél adenocarcinomáit, s néhány vizsgálatban a colorectalis daganatok, a nyelőcső laphámsejtes carcinomája szintén gyakoribbnak adódott a kontrollnépességhez képest [35].

\section{Hepatobiliaris érintettség}

Gluténérzékenységben gyakori az ismeretlen eredetű, enyhe hypertransaminasaemia (SGOT-SGPT emelkedés körülbelül a betegek 40\%-ánál látható). Megfigyelték, hogy a cryptogen hepatitises betegek körülbelül tizedénél diagnosztizálnak coeliakiát. A gluténmentes diéta hatására a transzaminázértékek is csökkenhetnek [36]. A legnagyobb számban előforduló májártalom, a „nem alkoholos zsírmáj" (NAFLD - non-alcoholic fatty liver 
disease) a coeliakiás betegek 7,5\%-ában diagnosztizálható. A klinikai megjelenés széles spektrumú, az enyhe fokú parenchymás károsodástól az idült gyulladásos májártalmon (sokszor nem reagál étrendre) túl akár súlyos májelégtelenség is jelentkezhet [36].

A patogenezis többtényezős, szerepe van a csökkent mucosalis barriermúködésnek, intestinalis dysbiosisnak, rendellenes epesav-anyagcserének és epeösszetételnek is. A mikrobiom által termelt proteolitikus enzimek fontosak a gliadinpeptidek emésztésében. Bizonyos törzsek felülreprezentáltsága nagyobb immunogenitású gliadinfragmentumokkal hozható összefüggésbe. A károsodott bélnyálkahártya-barrier miatt több idegen antigén, illetve bakteriális molekulák (például lipopoliszacharidok - LPS, rövid szénláncú zsírsavak - SCFA) jutnak a keringésbe, így járulva hozzá a kiterjedt gyulladásos állapothoz [36].

Autoimmunitás közvetítette kórképek - autoimmun hepatitis $(\mathrm{AIH})$, az epeutakat érintő primer biliaris cholangitis és primer szklerotizáló cholangitis - társulhatnak coeliakiához. Nincs azonban egyértelmúen bizonyított kapcsolat a betegségek között, nem része az ajánlásoknak a coeliakiára való kivizsgálás a betegeknél [36].

\section{Reproduktív rendszer}

A csökkent fertilitás hátterében állhat gluténérzékenység. A coeliakiás nőknél előfordulhat késői menarche, korai menopauza, szekunder amenorrhoea. Gyakori a HPG-tengely érintettsége (hypothalamo-pituitary-gonadal - hypothalamohypophysealis-gonadalis rendszer) [37]. A coeliakia az inzulinszerű növekedési faktorok (IGF, szomatomedinek) csökkenését okozhatja, és hozzájárulhat a gyermek növekedésbeli elmaradásához [38].

A kezeletlen GSE-ben észlelt kóros folyamatok mind a beágyazódásra, az érhálózat kialakulására, mind a lepényfejlődésre hatnak. A placentaris keringési elégtelenség részben a fokozott vérrögképződési hajlammal, részben a chorionboholy-szerkezet direkt immunmediált károsodásával magyarázható. A placentaris dysfunctio hajlamosít a magzat fejlődésének visszamaradására, alacsony születési súlyra (LBW), koraszülésre, súlyos esetben spontán vetélésre [39-41].

A transzglutamináz elleni antitestek kiemeltek a GSEben előforduló terhességi kórfolyamatokban. A TG-enzimek fontosak a beágyazódás, az élettani lepényfejlődés, a boholyrendszer kialakulásának folyamatában. Az antiTG2-antitestek kötődnek az endometrium endothelsejtjeihez, gátolva az angiogenezist, fokozzák a trophoblastsejtek apoptózisát $[39,41]$. A mátrix-metalloproteáz-2 (MMP-2) expressziójának csökkenése is az angiogenezist gátolja: az MMP-k a bazálmembrán átszervezésével járulnak hozzá új erek képződéséhez, felkészítve az endometriumot a blastocysta beágyazódására [39]. A sejteken belül az aktinhálózat dezorganizációja jellegzetes, csökkent a sejtmembrán-rugalmasság és -fluiditás [39].

$\mathrm{Az}$ IgG-autoantitestek átjutnak a lepényen, közvetlenül hatva a fejlődő magzatra. Ez fokozhatja az utód haj- lamát idegfejlődési rendellenességekre, későbbi életkorban diabetes, metabolicus dysfunctio, cardiovascularis betegségek kifejlődésére [40].

\section{Társuló autoimmun kórképek}

A coeliakiások hajlama fokozott más immunbetegségekekre. Genetikai tényezóként szerepelnek bizonyos HLAhaplotípusok s nem-HLA-gének. A megfelelő étrend kedvezően befolyásolhatja a társbetegségeket $[32,42]$.

A leggyakrabban coeliakiához társuló autoimmun kórkép az I-es típusú diabetes (TIDM), melyet a pancreas egyes antigénjeire irányuló antitesttermelés jelez (például glutamát-dekarboxiláz [GAD] elleni antitestek, szigetsejtellenes antitestek, inzulinellenes antitestek). A tanulmányok, amelyek a HLA-típus alapján fokozott coeliakiakockázatú betegeknél vizsgálták az AI-társbetegségek kialakulását, nem tudták egyértelmúen megerősíteni, hogy a korán megkezdett gluténmentes étrend megelőzheti a GSE vagy a társuló autoimmunitás kialakulását. A hajlam fokozódása részben genetikai okok révén lehetséges, a HLA-DR3/DQ2 haplotípus például a T1DM-betegek több mint felénél fordul elö, míg a DQ8 jelentős hajlamosító tényező. Coeliakiásoknál gluténmentes étrend mellett a TIDM-re jellemző az autoimmunantitest-szintek rendeződése, a betegség stabilizálódása várható $[42,43]$.

Szintén gyakori társbetegségek az autoimmun pajzsmirigygyulladások (Hashimoto- és Graves-thyreoiditis). Tekintvén a transzglutaminázok széles körü előfordulását, nem meglepő, hogy anti-tTG-autoantitest-depozitumok megfigyelhetők a pajzsmirigy szövetében, a follicularis sejtek plazmájában, a folliculusok űrterében és az interfollicularis terekben is, amelyek önmagukban is okozhatnak pajzsmirigymúködési rendellenességeket [44]. Más magyarázat a „molekuláris mimikri” jelenségét hangsúlyozza, a gliadinepitópok elleni antitestek keresztreagálhatnak pajzsmirigyantigénekkel.

A coeliakiások 14\%-ánál tapasztalható pajzsmirigyrendellenesség, ennek tekintélyesebb része (10\%) alulmúködés. A két „klasszikus” autoantitest mellett (antiTPO, antitireoglobulin) előfordulhatnak mikroszómaellenes antitestek [43]. A pozitív coeliakiaszerológia és a TPO-ellenes antitestek szintje sokszor korrelál. Sajnos fokozott a kockázat pajzsmirigy T-sejtes lymphomák kifejlődésére, amelyek prognózisa kedvezőtlen [34]. Megfigyelhető, hogy a gluténmentes étrend a társult pajzsmirigybetegségre kedvezően hathat [42].

A mellékvesekéreg-alulmúködéssel járó, autoimmun hátterü Addison-kór előfordulhat izoláltan vagy több mirigyet érintő autoimmun endocrinopathia részeként [31]. A közös előfordulás lehetőségét bizonyos HLAallélek, így elsősorban a DQ8-haplotípus közös előfordulása magyarázhatja [43].

A szervspecifikus autoimmun betegségre való fokozott hajlam NCGS-ben is megfigyelhető, elsősorban a Hashimoto-thyreoiditis gyakoribb előfordulásával talál- 
kozhatunk. A coeliakiához hasonlóan NCGS-hez is társulhat TIDM, de ritka a szisztémás autoimmun kórképekkel való közös előfordulás (progresszív szisztémás sclerosis, kevert kötőszöveti betegség - MCTD). NCGS fennállása mellett nagyjából $29 \%$ valószínúség van a betegnél AI-patogenezisú kór diagnosztizálására, ami jelentősen meghaladja az egészséges népességben tapasztalható 2-4\%-ot. Az antinukleáris antitestek (ANA) előfordulása $45 \%$ is lehet a betegcsoportban, ami az NCGS rendellenesen megváltozott immunszabályozó funkciói mellett szólhat [5].

\section{Kültakaró}

Főleg bőrtüneteiről ismert, de több szervrendszert érintő, immun inflammatoricus betegség a psoriasis. Jellemzô a fokozott cardiovascularis kockázat, az anyagcsererendellenességek, illetve az arthritis előfordulása. Psoriasis esetén nagyjából háromszoros kockázata van a coeliakia előfordulásának [45]. Genetikai faktoroknak lehet szerepük az asszociációban. A gluténmentes étrend a bőrgyógyászati tünetekre is kedvezően hathat [45].

Jellegzetes, gluténszenzitivitáshoz köthető epidermalis elváltozás a dermatitis herpetiformis (Duhring-kór). Patogenezisében az epidermalis transzglutamináz (eTG, transzglutamináz-3) ellen termelt autoantitesteknek van szerepük, képződésük gluténdependens. Nem mindig jár gyomor-bél rendszeri tünetekkel, bár gyakran kimutatható a duodenumbiopsziában a coeliakiára típusos nyálkahártya-laesio, még klinikai tünetek nélkül is. Tüneti kezelésre dapszon használható, de a kiváltó okot nem szünteti meg. Diagnózisában hasznos a bőrbiopszia immunfluoreszcens mikroszkópos vizsgálata, amellyel granuláris mintázatú IgA-depozitumok mutathatók ki az eTG ellen, amit perivascularis beszúrődés, lymphocytosis kísérhet.

\section{Mozgásszervi érintettség}

Coeliakiásoknál gyakori a csökkent csontásványianyagtartalom. Kialakulásának mechanizmusa többtényezős: kalcium- és D-vitamin-malabszorpció, citokindiszreguláció, hibás csontremodelling és autoimmunitás egyaránt közrejátszhat. Érdemes az igazolt coeliakiás betegek vizsgálata ilyen irányban, $\mathrm{s}$ fordítva is: igazolható csökkent csontásványianyag-tartalom esetén (ha azt az életkor vagy más nyilvánvaló betegség nem magyarázza) ajánlott coeliakia irányában vizsgálódni. A betegek standard kezelését a gluténmentes étrend mellett a kalcium- és D-vitaminpótlás jelentheti. A coeliakiaassszociált osteopenia kezelésére vonatkozó adatok korlátozottak, de egy tanulmány arra utal, hogy a zoledronát nem hatékony [46].

Az arthritis is gyakori coeliakiás betegeknél. Egy 1985ös vizsgálatban összefüggést találtak a szeronegatív arthritis és a coeliakia között, és megfigyelték, hogy a gluténmentes étrend jelentősen enyhített a tüneteken [47]. Megfigyelések támasztják alá, hogy mind a GSE, mind az NCGS összefügghet a fibromyalgiával [48].

\section{Összefoglalás, útravaló}

A coeliakia nem lokalizált immunbetegség, számos szervrendszert érinthet. A betegséggel kapcsolatos legfontosabb tudnivalók vázlatos áttekintése a 2. táblázatban található. Kezelése sokszor multidiszciplináris megközelítést, a szakterületek koordinált munkáját kívánja. Előfordulása növekszik, valamint „új” entitásként egyre ismertebb a nem coeliakiás gluténérzékenység (NCGS).

A fentiek alapján nem zárható ki coeliakia akkor sem, ha a beteg GI-panaszok nélkül, más szervrendszeri tünettel fordul orvoshoz. A betegség megjelenésére bármely életkorban számítani lehet. A társuló immunbetegségek lehetősége miatt az alapos kivizsgálás elengedhetetlen. Az egyetlen hatásos kezelés egyelőre az élethoszszig tartó gluténmentes étrend.

Tisztázatlan eredetű az úgynevezett NCGS, amelynek esetén egyre több evidencia szól immunológiai dysfunctiók mellett, a jellemző́k alapján inkább az innate immunrendszer múködési zavarával. A kórképpel foglalkozó kutatások száma valószínúleg jelentősen növekedni fog a közeljövőben. Feltétlenül szükség lenne specifikus betegségmarkerekre, diagnosztikai módszerekre.

Anyagi támogatás: A közlemény megírása anyagi támogatásban nem részesült.

Szerzői munkamegosztás: F. I.: Irodalomkutatás, szövegírás, szerkesztés. Z. É., B. Zs.: Irodalomkutatás, a leírtak áttekintése, azok helyességének ellenőrzése, szintetizálása, értékes szakmai tanácsadás és kiegészítések. A cikk végleges változatát mindhárom szerző elolvasta és jóváhagyta.

Érdekeltségek: A szerzőknek nincsenek érdekeltségeik.

\section{Irodalom}

[1] Parzanese I, Qehajaj D, Patrinicola F, et al. Celiac disease: from pathophysiology to treatment. World J Gastrointest Pathophysiol. 2017 ; 8: 27-38.

[2] Bodkhe R, Shetty SA, Dhotre DP, et al. Comparison of small gut and whole gut microbiota of first-degree relatives with adult celiac disease patients and controls. Front Microbiol. 2019; 10: 164.

[3] Arigliani M, Rech Morassutti F, Fabris M, et al. Coeliac disease in infants: antibodies to deamidated gliadin peptide come first! Ital J Pediatr. 2017; 43: 70.

[4] Gibson PR, Skodje GI, Lundin KE. Non-coeliac gluten sensitivity. J Gastroenterol Hepatol. 2017; 32(Suppl 1): 86-89.

[5] Carroccio A, D'Alcamo A, Cavataio F, et al. High proportions of people with nonceliac wheat sensitivity have autoimmune disease or antinuclear antibodies. Gastroenterology 2015; 149: 596603.el

[6] Szondy Z, Korponay-Szabó I, Király R, et al. Transglutaminase 2 in human diseases. BioMedicine 2017; 7: 15.

[7] $\mathrm{Yu} \mathrm{XB}$, Uhde M, Green PH, et al. Autoantibodies in the extraintestinal manifestations of celiac disease. Nutrients 2018; 10: 1123. 
[8] Hadjivassiliou M, Rao DG, Grünewald RA, et al. Neurological dysfunction in coeliac disease and non-coeliac gluten sensitivity. Am J Gastroenterol. 2016; 111: 561-567.

[9] Pacitto A, Paglino A, Di Genova L, et al. Celiac disease presenting with peripheral neuropathy in children: a case report. Int J Environ Res Public Health 2017; 14: 785.

[10] Krom H, Sprangers F, van den Berg R, et al. Transverse myelitis as manifestation of celiac disease in a toddler. Pediatrics 2017; 139: e20161381.

[11] Mitoma H, Adhikari K, Aeschlimann D, et al. Consensus paper: neuroimmune mechanisms of cerebellar ataxias. Cerebellum 2016; 15: 213-232.

[12] Hu WT, Murray JA, Greenaway MC, et al. Cognitive impairment and celiac disease. Arch Neurol. 2006; 63: 1440-1446.

[13] Pennisi M, Bramanti A, Cantone M, et al. Neurophysiology of the "celiac brain": disentangling gut-brain connections. Front Neurosci. 2017; 11: 498.

[14] Daulatzai MA. Non-celiac gluten sensitivity triggers gut dysbiosis, neuroinflammation, gut-brain axis dysfunction, and vulnerability for dementia. CNS Neurol Disord - Drug Targets 2015; 14: 110-131.

[15] Przybylska-Felus M, Furgala A, Zwolinska-Wcislo M, et al. Disturbances of autonomic nervous system activity and diminished response to stress in patients with celiac disease. J Physiol Pharmacol. 2014; 65: 833-841.

[16] Hadjivassiliou M, Sanders DS, Grünewald RA, et al. Gluten sensitivity: from gut to brain. Lancet Neurol. 2010; 9: 318-330.

[17] Hadjivassiliou M, Grünewald RA, Lawden M, et al. Headache and CNS white matter abnormalities associated with gluten sensitivity. Neurology 2001; 56: 385-388.

[18] Nenna R, Petrarca L, Verdecchia P, et al. Celiac disease in a large cohort of children and adolescents with recurrent headache: a retrospective study. Dig Liver Dis. 2016; 48: 495-498.

[19] Jericho H, Guandalini S. Extra-intestinal manifestation of celiac disease in children. Nutrients 2018; 10: 755.

[20] Bruni O, Dosi C, Luchetti A, et al. An unusual case of drug-resistant epilepsy in a child with non-celiac gluten sensitivity. Seizure 2014; 23: 674-676.

[21] Bashiri H, Afshari D, Babaei N, et al. Celiac disease and epilepsy: the effect of gluten-free diet on seizure control. Adv Clin Exp Med. 2016; 25: 751-754.

[22] Pratesi R, Modelli IC, Martins RC, et al. Celiac disease and epilepsy: favorable outcome in a child with difficult to control seizures. Acta Neurol Scand. 2003; 108: 290-293.

[23] Struck AF, Beinlich BR, Rutecki PA. A case of celiac disease, epilepsy, and cerebral calcifications with temporal lobe epilepsy. WMJ 2015; 114: 116-117.

[24] Peltola M, Kaukinen K, Dastidar P, et al. Hippocampal sclerosis in refractory temporal lobe epilepsy is associated with gluten sensitivity. J Neurol Neurosurg Psychiatry 2009; 80: 626-630.

[25] Ciaccio EJ, Lewis SK, Biviano AB, et al. Cardiovascular involvement in celiac disease. World J Cardiol. 2017; 9: 652-666.

[26] Pitocco D, Zaccardi F, Martini F, et al. The cardiovascular relevance of celiac disease. Diabetes Care 2012; 35: e20.

[27] Boskovic A, Kitic I, Prokic D, et al. Cardiomyopathy associated with celiac disease in childhood. Case Rep Gastrointest Med. 2012; 2012: 170760 .

[28] Santoro L, De Matteis G, Fuorlo M, et al. Atherosclerosis and cardiovascular involvement in celiac disease: the role of autoimmunity and inflammation. Eur Rev Med Pharmacol Sci. 2017; 21: 5437-5444.

[29] Baydoun A, Maakaron JE, Halawi H, et al. Hematological manifestations of celiac disease. Scand J Gastroenterol. 2012; 47: $1401-1411$
[30] Alaedini A, Green PH. Autoantibodies in celiac disease. Autoimmunity $2008 ; 41$ : 19-26.

[31] Samasca G, Sur G, Lupan I, et al. Celiac disease as an autoimmune condition. Cent Eur J Immunol. 2014; 39: 396-399.

[32] Bibbò S, Pes GM, Usai-Satta P, et al. Chronic autoimmune disorders are increased in coeliac disease. A case-control study. Medicine 2017; 96: e8562.

[33] Voigt W, Jordan K, Sippel C, et al. Severe thrombocytosis and anemia associated with celiac disease in a young female patient: a case report. J Med Case Rep. 2008; 2: 96.

[34] Smedby KE, Åkerman M, Hildebrand H, et al. Malignant lymphomas in coeliac disease: evidence of increased risks for lymphoma types other than enteropathy-type T cell lymphoma. Gut 2005; 54: 54-59.

[35] Catassi C, Bearzi I, Holmes GK. Association of celiac disease and intestinal lymphomas and other cancers. Gastroenterology 2005; 128(4 Suppl 1): S79-S86.

[36] Hoffmanova I, Sánchez D, Tučkova L, et al. Celiac disease and liver disorders: from putative pathogenesis to clinical implications. Nutrients 2018; 10: 892.

[37] Freeman HJ. Reproductive changes associated with celiac disease. World J Gastroenterol. 2010; 16: 5810-5814.

[38] Iughetti L, De Bellis A, Predieri B, et al. Growth hormone impaired secretion and antipituitary antibodies in patients with coeliac disease and poor catch-up growth after a long gluten-free diet period: a causal association? Eur J Pediatr. 2006; 165: 897903.

[39] Di Simone N, De Spirito M, Di Nicuolo F, et al. Potential new mechanisms of placental damage in celiac disease: anti-transglutaminase antibodies impair human endometrial angiogenesis. Biol Reprod. 2013; 89: 88.

[40] Sóñora C, Muñoz F, Del Río N, et al. Celiac disease and gynecoobstetrics complications: can serum antibodies modulate tissue transglutaminase functions and contribute to clinical pattern? Am J Reprod Immunol. 2011; 66: 476-487.

[41] Casella G, Orfanotti G, Giacomantonio L, et al. Celiac disease and obstetrical-gynecological contribution. Gastroenterol Hepatol Bed Bench 2016; 9: 241-249.

[42] Lauret E, Rodrigo L. Celiac disease and autoimmune-associated conditions. Biomed Res Int. 2013; 2013: 127589.

[43] Kumar V, Rajadhyaksha M, Wortsman J. Celiac disease-associated autoimmune endocrinopathies. Clin Diagn Lab Immunol. 2001; 8: 678-685.

[44] Naiyer AJ, Shah J, Hernandez L, et al. Tissue transglutaminase antibodies in individuals with celiac disease bind to thyroid follicles and extracellular matrix and may contribute to thyroid dysfunction. Thyroid 2008; 18: 1171-1178.

[45] De Bastiani R, Gabrielli M, Lora L, et al. Association between coeliac disease and psoriasis: Italian primary care multicentre study. Dermatology 2015; 230: 156-160.

[46] Kumar M, Rastogi A, Bhadada SK, et al. Effect of zoledronic acid on bone mineral density in patients of celiac disease: a prospective, randomized, pilot study. Indian J Med Res. 2013; 138: 882-887.

[47] Bourne JT, Kumar P, Huskisson EC, et al. Arthritis and coeliac disease. Ann Rheum Dis. 1985; 44: 592-598.

[48] Rodrigo L, Blanco I, Bobes J, et al. Clinical impact of a glutenfree diet on health-related quality of life in seven fibromyalgia syndrome patients with associated celiac disease. BMC Gastroenterol. $2013 ; 13$ : 157 .

(Fedor István dr.,

Debrecen, Móricz Zs. krt. 22., 4032 e-mail: vejne@med.unideb.hu)

A cikk a Creative Commons Attribution 4.0 International License (https://creativecommons.org/licenses/by/4.0/) feltételei szerint publikált Open Access közlemény, melynek szellemében a cikk bármilyen médiumban szabadon felhasználható, megosztható és újraközölhetö, feltéve, hogy az eredeti szerző és a közlés helye, illetve a CC License linkje és az esetlegesen végrehajtott módositások feltüntetésre kerülnek. (SID_1) 